\title{
Dual Role for Astroglial Copper-Assisted Polyamine Metabolism during Intense Network Activity
}

\author{
Zsolt Szabó $^{1}$, Márton Péter ${ }^{1,2}$, László Héja ${ }^{1, *,+}$ and Julianna Kardos ${ }^{1,+}$ (D) \\ 1 Functional Pharmacology Research Group, Research Centre for Natural Sciences, \\ Institute of Organic Chemistry, H-1117 Budapest, Hungary; szabo.zsolt@ttk.hu (Z.S.); \\ peter.marton@ttk.hu (M.P.); kardos.julianna@ttk.hu (J.K.) \\ 2 Hevesy György Ph.D. School of Chemistry, ELTE Eötvös Loránd University, H-1117 Budapest, Hungary \\ * Correspondence: heja.laszlo@ttk.hu; Tel.: +36-1-382-6619 \\ + These authors contributed equally to this work.
}

Citation: Szabó, Z.; Péter, M.; Héja, L.; Kardos, J. Dual Role for Astroglial Copper-Assisted Polyamine Metabolism during Intense Network Activity. Biomolecules 2021, 11, 604. https://doi.org/10.3390/ biom11040604

Academic Editor: Serguei Skatchkov

Received: 4 March 2021

Accepted: 14 April 2021

Published: 19 April 2021

Publisher's Note: MDPI stays neutral with regard to jurisdictional claims in published maps and institutional affiliations.

Copyright: (c) 2021 by the authors. Licensee MDPI, Basel, Switzerland. This article is an open access article distributed under the terms and conditions of the Creative Commons Attribution (CC BY) license (https:// creativecommons.org/licenses/by/ $4.0 /)$.

\begin{abstract}
Astrocytes serve essential roles in human brain function and diseases. Growing evidence indicates that astrocytes are central players of the feedback modulation of excitatory Glu signalling during epileptiform activity via Glu-GABA exchange. The underlying mechanism results in the increase of tonic inhibition by reverse operation of the astroglial GABA transporter, induced by Glu$\mathrm{Na}^{+}$symport. GABA, released from astrocytes, is synthesized from the polyamine (PA) putrescine and this process involves copper amino oxidase. Through this pathway, putrescine can be considered as an important source of inhibitory signaling that counterbalances epileptic discharges. Putrescine, however, is also a precursor for spermine that is known to enhance gap junction channel communication and, consequently, supports long-range $\mathrm{Ca}^{2+}$ signaling and contributes to spreading of excitatory activity through the astrocytic syncytium. Recently, we presented the possibility of neuron-glia redox coupling through copper $\left(\mathrm{Cu}^{+} / \mathrm{Cu}^{2+}\right)$ signaling and oxidative putrescine catabolism. In the current work, we explore whether the $\mathrm{Cu}^{+} / \mathrm{Cu}^{2+}$ homeostasis is involved in astrocytic control on neuronal excitability by regulating PA catabolism. We provide supporting experimental data underlying this hypothesis. We show that the blockade of copper transporter (CTR1) by $\mathrm{AgNO}_{3}(3.6 \mu \mathrm{M})$ prevents GABA transporter-mediated tonic inhibitory currents, indicating causal relationship between copper $\left(\mathrm{Cu}^{+} / \mathrm{Cu}^{2+}\right)$ uptake and the catabolism of putrescine to GABA in astrocytes. In addition, we show that $\mathrm{MnCl}_{2}(20 \mu \mathrm{M})$, an inhibitor of the divalent metal transporter DMT1, also prevents the astrocytic Glu-GABA exchange. Furthermore, we observed that facilitation of copper uptake by added $\mathrm{CuCl}_{2}$ $(2 \mu \mathrm{M})$ boosts tonic inhibitory currents. These findings corroborate the hypothesis that modulation of neuron-glia coupling by copper uptake drives putrescine $\rightarrow$ GABA transformation, which leads to subsequent Glu-GABA exchange and tonic inhibition. Findings may in turn highlight the potential role of copper signaling in fine-tuning the activity of the tripartite synapse.
\end{abstract}

Keywords: astroglial tonic inhibitory feedback; astroglial GABA transporter; copper transporter CTR1; putrescine catabolism; copper amino oxidase; Cx43 gap junction channel

\section{Introduction}

Several lines of evidence along with theoretical considerations discuss the potential of neuron-glia coupling in healthy and diseased brain [1-8]. Beside neuronal activitydependent astroglial energy metabolisms [9], neuron-glia coupling may involve $\mathrm{K}^{+}, \mathrm{Ca}^{2+}$ and $\mathrm{Na}^{+}$signalling through gap junction channels (GJCs), astroglial Glu-Na ${ }^{+}$symportevoked release of GABA (Glu-GABA exchange), glycine, glutamine and other neuro/glio transmitters or modulators [10-24]. In particular, astroglial GABA release mechanisms involve inside-out (reverse) operation of astroglial GABA transporters GAT-2/3 [15,25,26] or bestrophin 1 channels [27-29]. Nevertheless, GABA may travel far away from the tripartite synapse through astrocytic Cx43 GJCs, also facilitated by polyamines (PAs) [30,31]. 
Central inhibition is controlled by the major inhibitory neurotransmitter GABA that is mainly formed by decarboxylation of Glu in neurons. In midway dopaminergic neurons, however, it is formed from putrescine by the copper amino oxidase (CAO) and aldehyde dehydrogenase 1a1 enzymes [32]. Several lines of evidence suggest that the catabolism of putrescine to GABA in astrocytes $[33,34]$ is the dominant source of the gliotransmitter GABA [15,26,28,35-38]. On the molecular level, the cofactor 2,4,5-trihydroxyphenylalanine quinone (topaquinone; TPQ), present in the D4 catalytic centre of mammalian CAOs is featured by three conserved hystidines coordinating the copper ion involved in TPQ biogenesis [39]. It is conceivable therefore, that GABA formation from putrescine [38] may in turn be reliant on copper $\left(\mathrm{Cu}^{+} / \mathrm{Cu}^{2+}\right)$ homeostasis.

As an alternative to neuronal source-target-physiology scheme of copper signaling [40], we hypothesized a gliocentric scheme of redox signaling mediated by $\mathrm{Cu}^{+} / \mathrm{Cu}^{2+}[41]$. The scheme suggests that copper released from depolarized nerve endings [42] and taken up primarily by the high-affinity copper transporter (CTR1) [43,44] may enhance the coppercatalyzed oxidative putrescine $\rightarrow$ GABA transformation, boosting astroglial Glu-GABA exchange, thereby tonic inhibition.

In order to assess the potential role for CTR1 in putrescine metabolism and GluGABA exchange, here we explored whether inhibition of CTR1 by $\mathrm{Ag}^{+}$[45] or inhibition of the divalent metal transporter DMT1 by $\mathrm{Mn}^{2+}$ [46] affect the Glu-GABA exchangecontrolled tonic inhibition in rat hippocampal slices. We hypothesized that lowering astroglial $\mathrm{Cu}^{+} / \mathrm{Cu}^{2+}$ level by CTR1 blockade may disrupt the ornithine $\rightarrow$ putrescine $\rightarrow$ GABA catabolism pathway [47] and consequently reduce the tonic inhibition mediated by the astrocytic Glu-GABA exchange. CTR1 blockade, however, may also diminish the putrescine $\rightarrow$ spermidine $\rightarrow$ spermine transform [48] via reduction of astroglial Cx43 GJC signaling [30,31]. The actual redox potential dependent balance of inhibition and excitation may place putrescine formation and metabolism in the centre of molecular mechanisms underlying many cellular functions of PAs [49-63]. This might have repercussions on pharmacoresistant epilepsy [64,65] or tubular sclerosis seizures [66] or memory [67,68].

\section{Materials and Methods}

\subsection{Animals}

Animals were kept and used in accordance with standard ethical guidelines and approved by the local Animal Care Committee, the Government Office for Pest County (Reference Nos. PEI/001/3671-4/2015 and PE/EA/3840-4/2016), the Hungarian Act of Animal Care and Experimentation (1998, XXVIII, section 243), European Communities Council Directive 24 November, 1986 (86/609/EEC) and EU Directive 2010/63/EU on the use and treatment of animals in experimental laboratories. All efforts were made to reduce animal suffering and the number of animals used.

\subsection{Buffers}

Buffers contained in mM ACSF: $129 \mathrm{NaCl}, 5 \mathrm{KCl}, 1.6 \mathrm{CaCl}_{2}, 1.8 \mathrm{MgSO}_{4}, 1.25 \mathrm{NaH}_{2} \mathrm{PO}_{4}$, $21 \mathrm{NaHCO}_{3}, 10$ glucose ( $\mathrm{pH}$ 7.4); nominally $\mathrm{Mg}^{2+}$-free ACSF was prepared as control ACSF with no added $\mathrm{Mg}^{2+}$ (we estimated the $\mathrm{Mg}^{2+}$ concentration of this buffer to be approximately $1 \mu \mathrm{M})$. Pharmacological assessment was done by the following compounds: $\mathrm{MnCl}_{2}(20 \mu \mathrm{M}), \mathrm{AgNO}_{3}(3.6 \mu \mathrm{M}), \mathrm{CuCl}_{2}(2 \mu \mathrm{M})$ - all purchased from Sigma-Aldrich, Schnelldorf, Germany, SNAP-5114 (100 $\mu \mathrm{M}$, Tocris, Bristol, UK).

\subsection{Slice Preparation}

Transverse, $300 \mu \mathrm{m}$ thick hippocampal-entorhinal slices from 12- to 15-day-old Wistar rats (Toxicoop, Budapest, Hungary) were prepared in modified ACSF (75 mM sucrose, $87 \mathrm{mM} \mathrm{NaCl}, 2.5 \mathrm{mM} \mathrm{KCl}, 1.25 \mathrm{mM} \mathrm{NaH}_{2} \mathrm{PO}_{4}, 7 \mathrm{mM} \mathrm{MgSO} 4,0.5 \mathrm{mM} \mathrm{CaCl}, 25 \mathrm{mM}$ $\mathrm{NaHCO}_{3}, 25 \mathrm{mM}$ glucose, continuously bubbled with $95 \% \mathrm{O}_{2}+5 \% \mathrm{CO}_{2}$ gas mixture) at $4{ }^{\circ} \mathrm{C}$. Slices were incubated in an interface-type chamber that was continuously circulated 
with ACSF for one hour at $37^{\circ} \mathrm{C}$ (followed by incubation at room temperature) before performing the experiments.

\subsection{In Vitro Electrophysiology}

Electrophysiological recordings were performed at $31^{\circ} \mathrm{C}$. Signals were recorded with Multiclamp700A amplifiers (Axon Instruments, Foster City, CA, USA), low-pass filtered at $2 \mathrm{kHz}$ and digitized at $20 \mathrm{kHz}$ (Digidata1320A, Axon Instruments). For single cell recording CA1 pyramidal cells were identified visually. Pipettes (4 to $5 \mathrm{M} \Omega$ ) were filled with a solution containing (in mM) $130 \mathrm{CsMeSO}_{3}, 10 \mathrm{NaCl}, 0.05 \mathrm{CaCl}_{2}, 2 \mathrm{ATP}$ (magnesium salt), 1 EGTA and 10 HEPES ( $\mathrm{pH}$ set to 7.3 with $1 \mathrm{~N} \mathrm{CsOH}$ ). To suppress escape action currents $5 \mathrm{mM}$ QX 314 (Tocris, Bristol, UK) was added. Cells were voltage-clamped at $0 \mathrm{mV}$ (corrected for a calculated junction potential of $+15 \mathrm{mV}$ ) to record GABAergic (outward) currents. Input resistance was $150.7 \pm 14.0 \mathrm{M} \Omega$. If signs of seal deterioration or cell closure occurred ( $>20 \%$ change in the access resistance) the recordings were discarded. Synaptic recordings were made for 10 to $20 \mathrm{~min}$ in control conditions following 10 to $20 \mathrm{~min}$ of $100 \mu \mathrm{M}$ SNAP-5114 application and 10 to 20 min washout.

\subsection{Data Evaluation}

Holding currents were determined as previously described [26]. All-point histograms were plotted for each $1 \mathrm{~s}$ period of experimental traces. A Gaussian was fitted to the unskewed part of the histogram and the position of the center of the fitted Gaussian was used as the holding current. Values during SLEs were not included in data evaluation.

Spontaneous IPSCs were analyzed by a custom MATLAB script, based on the detection method of the MiniAnalysis software (Synaptosoft, Decatur, GA, USA), using $10 \mathrm{pA}$ as amplitude threshold. IPSCs with event frequency values greater than $300 \mathrm{~Hz}$ were excluded to avoid duplicate IPSC detection.

Unless stated otherwise data are expressed as means \pm S.E.M. and were analyzed using Student's paired t-test or one-way analysis of variances with Bonferroni post hoc tests (OriginPro 8.0). A value of $p<0.05$ was considered significant.

\section{Results}

3.1. Assessing Astroglial GABA Transporter-Specific Component of Tonic Inhibitory Current in the Low- $\left[\mathrm{Mg}^{2+}\right]$ Model of Experimental Epilepsy

To explore whether copper uptake plays a role in putrescine-dependent tonic inhibition provided by astrocytes $[25,26]$, we measured inhibitory currents on hippocampal CA1 neurons. Rat hippocampal slices were exposed to low- $\left[\mathrm{Mg}^{2+}\right]$ ACSF which enhances excitatory activity and triggers the astrocytic Glu/GABA exchange mechanism [25,26]. This mechanism is mediated by the astrocytic GAT-2/3 GABA transporters that are reversed following increased Glu uptake and elevated intracellular GABA level. We blocked GAT-2/3 transporters by their specific, non-transportable inhibitor SNAP-5114 $(100 \mu \mathrm{M})$ to determine the GAT-2/3 mediated component of the tonic current measured on CA1 neurons. $\mathrm{CsMeSO}_{3}$-based pipette solution (with added QX 314) was used to isolate GABAergic (outward directed) currents in voltage clamped configuration by applying $0 \mathrm{mV}$ holding potential.

Under control condition, in low-[ $\left.\mathrm{Mg}^{2+}\right]$ ACSF we observed that the blockade of GAT$2 / 3$ transporters by $100 \mu \mathrm{M}$ SNAP-5114 decreased the tonic current from $94.4 \pm 20.6 \mathrm{pA}$ to $72.8 \pm 16.1 \mathrm{pA}$ (Figure 1). The decrease was found to be significant $(p=0.04, \mathrm{~N}=3$ ). The GABAergic origin of the measured current has previously been validated, since SNAP-5114 had no effect on the tonic current in the presence of the $\mathrm{GABA}_{\mathrm{A}}$ antagonist picrotoxin [26]. The observed decrease in the tonic current is not due to a change in IPSC kinetics, since neither the amplitude, nor the frequency of IPSCs were altered significantly in the presence of SNAP-5114 (Figure 1). 

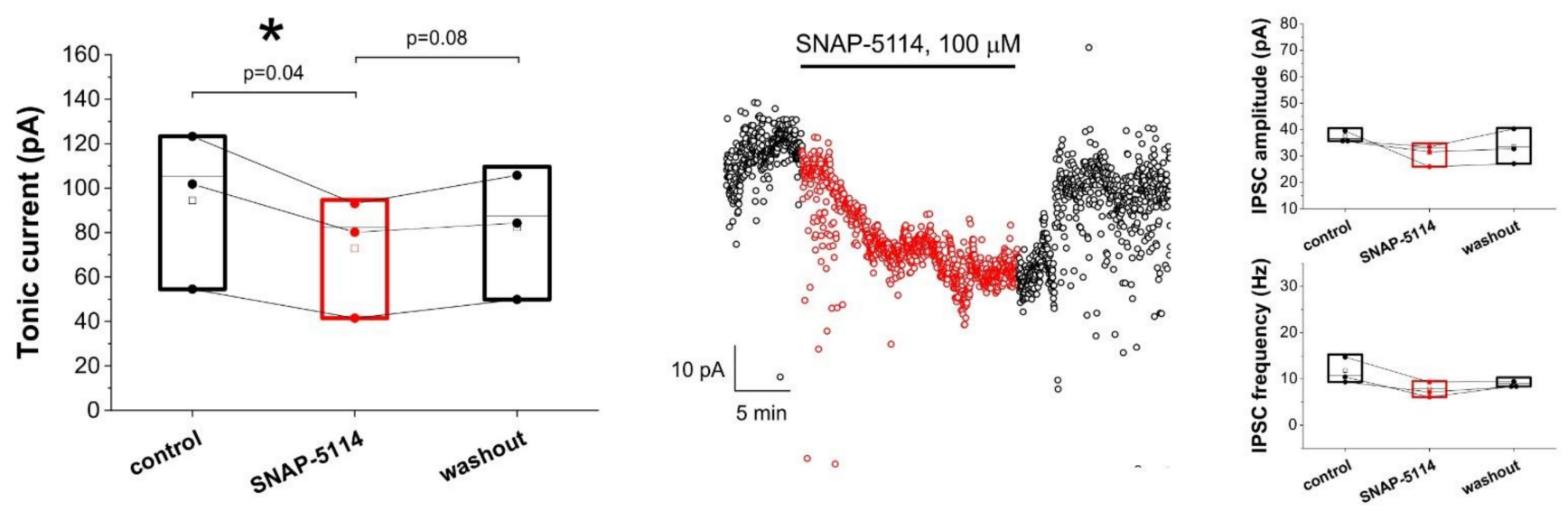

Figure 1. Glial GABA transporters release GABA and generate tonic inhibition in low- $\left[\mathrm{Mg}^{2+}\right]$ ACSF. Left: Box-chart representation of GABAergic baselines during control condition, in the presence of SNAP-5114 and washout. Box edges represent 25 th, 50th and 75 th percentile, open squares represent means, circles connected by lines represent paired individual baseline values. $(\mathrm{N}=3)$. Middle: baseline currents plotted at $1 \mathrm{~s}$ intervals in a selected experiment. Right: amplitude and frequency of inhibitory postsynaptic currents (IPSCs). Box edges represent 25th, 50th and 75th percentile, open squares represent means, circles connected by lines represent paired individual baseline values. $(\mathrm{N}=3)$. Neither amplitude, nor frequency changed significantly due to SNAP-5114 application ( $p=0.31$ and $p=0.29$, respectively). Black symbols represent control and washout periods, red symbols represent SNAP-5114 application in all figures.

\subsection{Effects of Added $A g N O_{3}$ or $\mathrm{MnCl}_{2}$ on the GAT-2/3 Specific Tonic Inhibitory Component}

In contrast to control conditions, SNAP-5114 did not significantly affect tonic currents when we blocked astrocytic copper uptake beforehand. Applying the copper transporter (CTR1) inhibitor $\mathrm{AgNO}_{3}(3.6 \mu \mathrm{M})$, the GAT-2/3 mediated tonic current disappeared and GAT-2/3 blockade even produced an intermediate, non-significant increase of baseline current $(94.7 \pm 14.4 \mathrm{pA}$ in the absence vs. $109.4 \pm 14.8 \mathrm{pA}$ in the presence of SNAP-5114, $p=0.18, \mathrm{~N}=5$ ) (Figure 2A), suggesting that GAT-2/3 transporters operate in the normal mode, taking up GABA from the extracellular space when astrocytic GABA synthesis is impaired due to copper shortage. Surprisingly, addition of $20 \mu \mathrm{M} \mathrm{MnCl}$, a supposed inhibitor of another class of astrocytic copper transporters, the divalent metal transporter 1 (DMT1), resulted in the increase of tonic current from $84.9 \pm 8.3 \mathrm{pA}$ to $98.7 \pm 11.6 \mathrm{pA}$ ( $p=0.024, \mathrm{~N}=5)$, which was not significantly altered by the presence of SNAP-5114 (101.6 $\pm 14.3 \mathrm{pA}$ in the presence of SNAP-5114, $p=0.49, \mathrm{~N}=5$ ) (Figure 2B). The increased tonic current in the presence of $\mathrm{MnCl}_{2}$, however, may be due to an alternative effect of $\mathrm{Mn}^{2+}$, since $\mathrm{MnCl}_{2}$ also increased IPSC frequency (Figure 2B). It is to note in this regard that $\mathrm{Mn}^{2+}$ is known to increase extracellular GABA concentration by altering the expression level of GAT-1 [69], but on the timescale of our experiments this is expected to have a negligible effect.

These results suggest that the suppression of copper entry into astrocytes by $\mathrm{Ag}^{+}$leads to decreased GABA formation and consequently prevents GABA release through GAT-2/3 when it is operating in the reverse mode. 

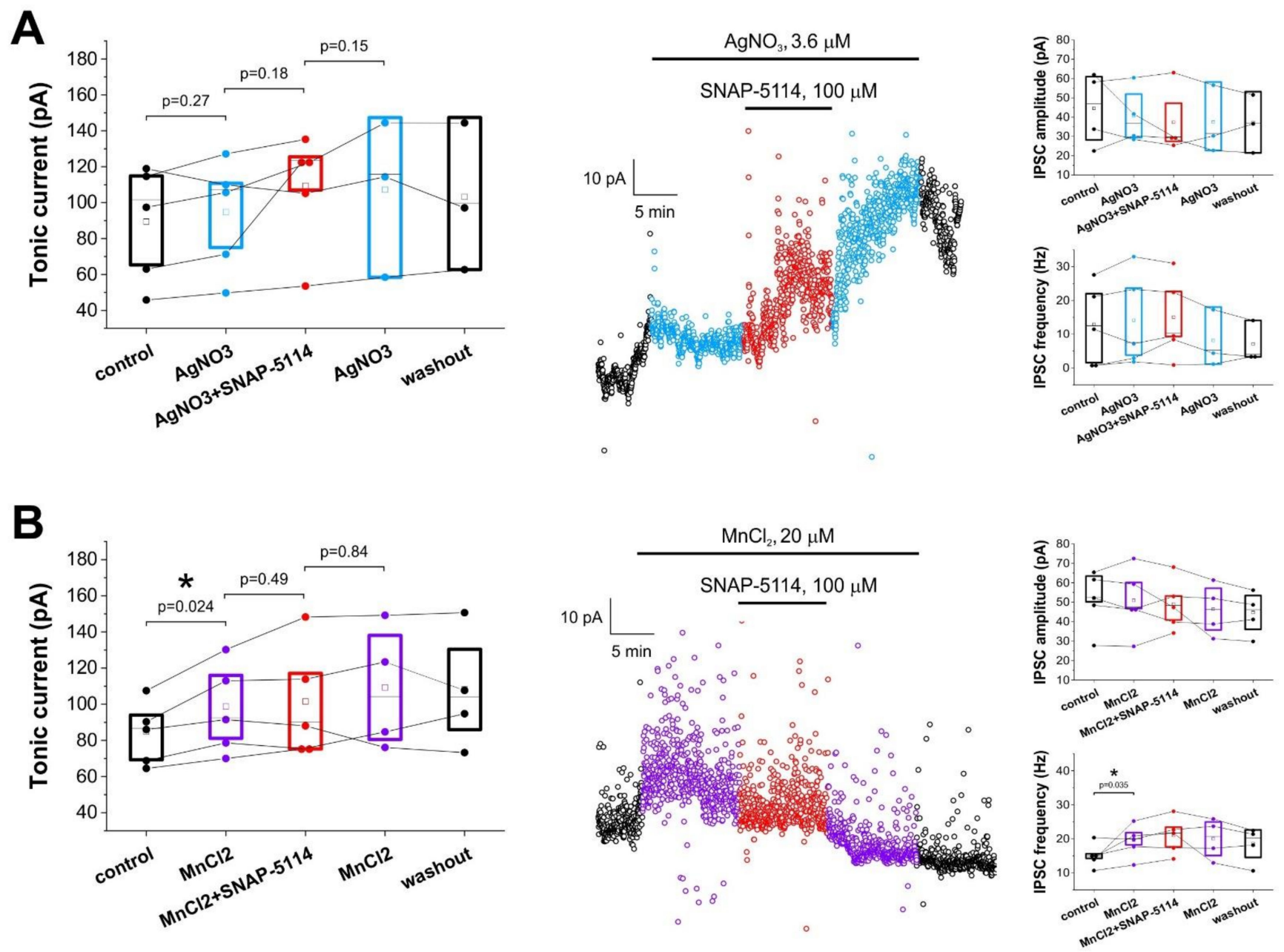

Figure 2. Added $\mathrm{AgNO}_{3}$ or $\mathrm{MnCl}_{2}$ prevents $\mathrm{GABA}$ release through glial GABA transporters in low-[Mg $\left.{ }^{2+}\right]$ ACSF. Effect of GAT-2/3 blockade by $100 \mu \mathrm{M}$ SNAP-5114 on the holding current of voltage clamp recording segments in low-[Mg $\left.{ }^{2+}\right]$ ACSF in the presence of of $3.6 \mu \mathrm{M} \mathrm{AgNO}_{3}$ (A) or $20 \mu \mathrm{M} \mathrm{MnCl}_{2}$ (B). Left: Box-chart representation of GABAergic baselines during control condition, $\mathrm{AgNO}_{3}$ or $\mathrm{MnCl}_{2}$ application, addition of SNAP-5114 and washout. Box edges represent 25th, 50th and 75th percentile, open squares represent means, circles connected by lines represent paired individual baseline values. ( $\mathrm{N}=5$ for both $\mathrm{AgNO}_{3}$ and $\mathrm{MnCl}_{2}$ ). Middle: baseline currents plotted at $1 \mathrm{~s}$ intervals in a selected experiment. Right: amplitude and frequency of inhibitory postsynaptic currents (IPSCs). Box edges represent 25th, 50th and 75th percentile, open squares represent means, circles connected by lines represent paired individual baseline values. $\left(\mathrm{N}=5\right.$ for both $\mathrm{AgNO}_{3}$ and $\left.\mathrm{MnCl}_{2}\right)$. Neither amplitude, nor frequency changed significantly in the presence of $\operatorname{AgNO}_{3}(p=0.31$ and $p=0.29$, respectively), however $\mathrm{MnCl}_{2}$ significantly increased the frequency of IPSCs $(p=0.035)$. Black symbols represent control and washout periods, light blue and purple symbols represent $\mathrm{AgNO}_{3}$ or $\mathrm{MnCl}_{2}$ applications, respectively, red symbols represent simultaneous SNAP-5114 and $\mathrm{AgNO}_{3}$ or $\mathrm{MnCl}_{2}$ application in all figures.

\subsection{Direct Copper Application Generates Tonic Current}

We have shown above that inhibition of astrocytic copper uptake reduces the GAT$2 / 3$ mediated tonic inhibitory current component, likely due to the reduced astrocytic GABA formation from putrescine. Next, we explored whether the tonic inhibitory current can be directly induced by stimulating this pathway (Figure 3). We added $2 \mu \mathrm{M} \mathrm{CuCl}_{2}$ to trigger copper uptake. Copper application did induce a significant increase in the baseline current measured on CA1 neurons $(83.1 \pm 6.7 \mathrm{pA}$ in control vs. $104.2 \pm 6.7 \mathrm{pA}$, $p=0.28, \mathrm{~N}=5$ ), suggesting that exogenous copper increases the astrocytic GABA level. We also demonstrated that the observed increase in the tonic current is not due to a direct effect of copper on either GABA receptors, extracellular GABA level or voltagegated $\mathrm{Ca}^{2+}$ channels, since IPSC frequency and amplitude were not affected by $\mathrm{CuCl}_{2}$ 
application (Figure 3). Blockade of astrocytic GAT-2/3 transporters in this condition did not decrease the tonic current, but significantly reduced the copper-initiated increase, which continued to develop after the removal of SNAP-5114 (Figure 3). The ability of SNAP-5114 to mitigate the exogenous copper-induced enhancement of tonic current suggests that GAT-2/3 transporters are involved in the resulting GABA release. However, its inability to completely block the tonic current indicates that other efflux pathways, for example via the Bestrophin 1 channel [21] also needs to be considered.
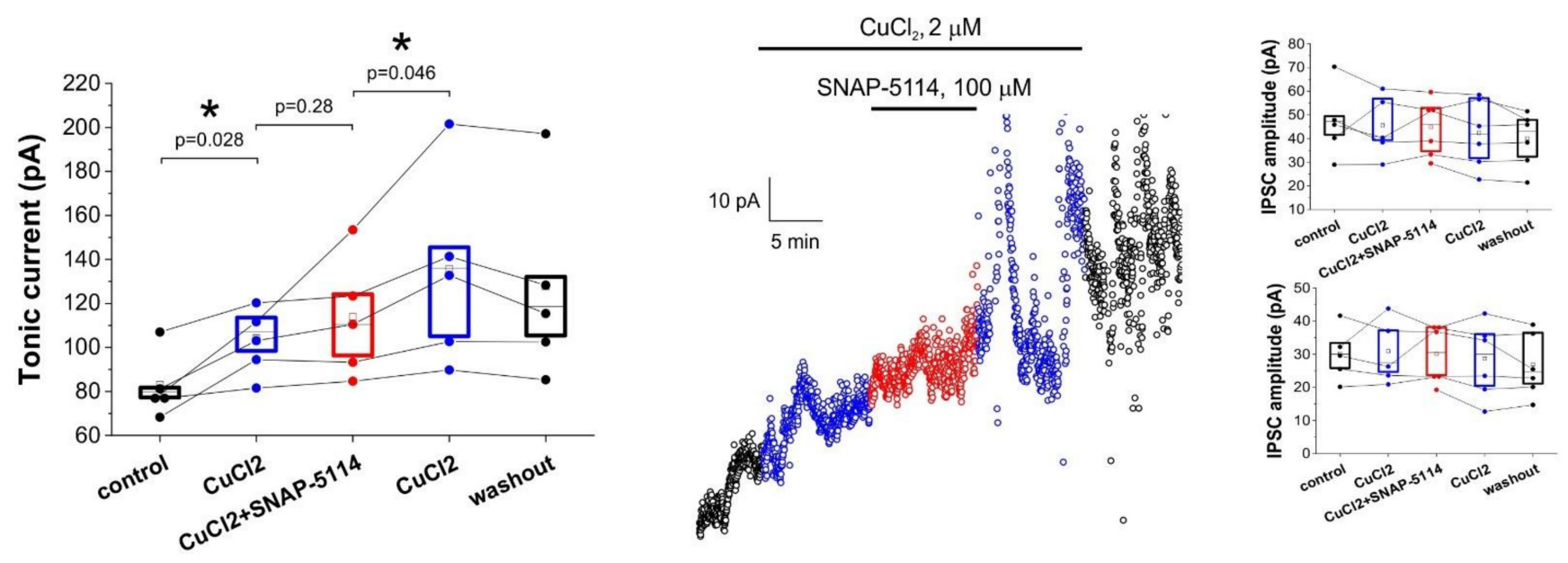

Figure 3. Added $\mathrm{CuCl}_{2}$ induces tonic inhibition which can be reduced by blocking glial GABA transporters in low-[Mg $\left.{ }^{2+}\right]$ ACSF. Left: Box-chart representation of GABAergic baselines during control condition, $\mathrm{CuCl}_{2}$ application, addition of SNAP-5114 and washout. Box edges represent 25th, 50th and 75th percentile, open squares represent means, circles connected by lines represent paired individual baseline values. $(\mathrm{N}=5)$. Middle: baseline currents plotted at $1 \mathrm{~s}$ intervals in a selected experiment. Large fluctuations in baseline current after SNAP-5114 washout correspond to seizure-like events. Right: amplitude and frequency of inhibitory postsynaptic currents (IPSCs). Box edges represent 25th, 50th and 75th percentile, open squares represent means, circles connected by lines represent paired individual baseline values. $(\mathrm{N}=5)$. Neither amplitude, nor frequency changed significantly due to SNAP-5114 application ( $p=0.81$ and $p=0.82$, respectively). Black symbols represent control and washout periods, blue symbols represent $\mathrm{CuCl}_{2}$ application, red symbols represent simultaneous SNAP-5114 and $\mathrm{CuCl}_{2}$ application in all figures.

\section{Discussion}

We investigated the relationship between copper uptake, PA metabolism and subsequent astrocytic regulation of neuronal excitability. First, we reproduced our previous observation that blockade of the astroglial GAT-2/3 transporter leads to the decrease of tonic inhibitory currents in low-[ $\left.\mathrm{Mg}^{2+}\right]$ activated rat hippocampal slices (control). Under this condition, inhibition of CTR1 by added $\left.\mathrm{Ag}^{+}(3.6 \mu \mathrm{M} \mathrm{AgNO})_{3}\right)$ eliminated the appearance of GAT-2/3 mediated tonic inhibitory currents. Since the active moiety, astrocytic GABA that mediates tonic inhibition is synthesized from putrescine, our results highlight the contribution of $\mathrm{Cu}^{+} / \mathrm{Cu}^{2+}$ ratio to oxidative putrescine $\rightarrow$ GABA catabolism in astrocytes $[15,21,25,26,28,29,33,34,36,70]$.

Another potential pathway to discuss is the activity-dependent release of $\mathrm{Zn}^{2+}[71,72]$, co-released with Glu [73]. The preferential binding of $\mathrm{Zn}^{2+}$ to astroglial GAT-3 versus GAT-2 [74] was explained by the difference in the extracellular coordination of $\mathrm{Zn}^{2+}$ [75,76]. In hGAT-3, the coordination of $\mathrm{Zn}^{2+}$ by the extracellular EL2 loop residues (Asn190, Tyr191, Ser192) combined with residues located at the tip of the TM7 helix (Phe358, Met359, Tyr361) suggests that the blockade takes place in the outward facing open conformation of GAT3 [76]. We expect that $\mathrm{Cu}^{2+}$ or $\mathrm{Mn}^{2+}$ may substitute $\mathrm{Zn}^{2+}$ in the function of stabilizing the extracellular GAT-3 gate in the open conformation by shuffling sulphur lone-pair and aromatic $\pi$ electrons (MetAro effect) [77,78]. Stabilization of the open GAT-3 conformation by $\mathrm{Cu}^{2+} / \mathrm{Mn}^{2+}$ can also be explained by a similar MetAro effect. Since driving force of 
astrocytic GABA favours GABA release in the low- $\left[\mathrm{Mg}^{2+}\right]$ medium, constant opening of GAT-3 may increase tonic inhibitory currents that were shown to be inhibited by SNAP5114. In fact, elevated extracellular concentration of GABA was measured in the striatum of $\mathrm{Mn}^{2+}$-exposed rats, suggesting impairment of clearance of or enhancement of release of GABA by GABA transporters [79]. In principle, the displacement of $\mathrm{Zn}^{2+}$ by $\mathrm{Cu}^{2+} / \mathrm{Mn}^{2+}$ might also occur at other tripartite synapse targets including various Glu and GABA receptor and transporter subtypes [80-87]. These clues, however, are not likely to affect tonic inhibition via the astroglial Glu-GABA exchange mechanism, therefore they would not be sensitive to SNAP-5114.

Unexpectedly, tonic inhibitory currents elicited by ten-minute single application of $2 \mu \mathrm{M} \mathrm{Cu}^{2+}$ significantly exceeds those recorded with added $20 \mu \mathrm{M} \mathrm{Mn}^{2+}$ alone or in combination with the GAT-2/3 specific inhibitor SNAP-5114. Furthermore, the significantly higher level of tonic inhibition persists after washout, suggesting that added $\mathrm{Cu}^{2+}$ elicits a long-lasting shift of neuronal excitability. We propose that the tonic inhibitory currents enhancement by $2 \mu \mathrm{M} \mathrm{CuCl}_{2}$-that substantially exceeds the $20 \mu \mathrm{M} \mathrm{MnCl}_{2}$-induced GAT-3 regulated tonic inhibitory currents—can be traced back to some additional GABA release mechanisms. At first approximation, we focused on data linked to PA metabolism. Literature data show that added $\mathrm{Mn}^{2+}$ dose-dependently $(1-100 \mu \mathrm{M})$ increases putrescine content (3.2-4.5 nmol/mg protein) in human SH-SY5Y cells [88]. Besides, the increase of putrescine content positively correlates with the PA metabolite $\mathrm{N}$-acetylspermidine, but negatively with GABA related metabolites [88]. It is plausible therefore, that the $\mathrm{Cu}^{2+}$ induced enhancement of putrescine $\rightarrow$ GABA catabolism also boosts the putrescine $\rightarrow$ spermidine $\rightarrow$ spermine metabolism pathway. Spermine may in turn support astroglial GJC coupling [30,31], long-range GABA trafficking via Cx43 GJCs and release of GABA through purinergic $\mathrm{P}_{2} \mathrm{X}_{7}$ receptor pore [89] or via connexon hemichannels like Glu [90]. These alternative GABA release mechanisms, independent of GAT-2/3 mediated gliotransmission remains to be explored in the future.

Data on depolarization-induced bulk copper release amounts to $\geq 100 \mu \mathrm{M}$ synaptic transients (for a detailed discussion see [41]). Synaptic copper transients spread over the extrasynaptic compartment by a steep $\geq 100 \mu \mathrm{M}$ (synaptic) $\rightarrow \leq 1 \mu \mathrm{M}$ (extra-synaptic) copper gradient [91,92]. The $K_{m}$ values characterizing copper uptake by CTR1 range between $1 \mu \mathrm{M}$ and $6 \mu \mathrm{M}$ [44]. These findings explain the efficient extra-cellular modulation of astroglial CTR1 by adding $2 \mu \mathrm{M} \mathrm{CuCl}_{2}$. Our data provide supporting evidence on the gliocentric scheme of copper signaling [41] by relating astroglial copper uptake to feedback inhibition of neuronal excitability. Multiple mechanisms comprising several steps can be identified to interpret these data (Figure 4):

(1) Uptake of extrasynaptic $\mathrm{Cu}^{2+}$ is mediated by the astroglial CTR1 that provides copper for CAO. This pathway can be blocked by $\mathrm{Ag}^{+}$. (2) Changes in intracellular copper concentration affect $\mathrm{CAO}$ activity. Although copper loading into the $\mathrm{CAO}$ active site is considered to be an irreversible process, the rate by which the loading occurs does depend on solute copper concentration. An experimentally validated kinetic model developed by Adelson et al. [93] showed that $12 \mathrm{~h}$ loading with 0.8 equiv. $\mathrm{Cu}^{2+}$ is comparable with 30 min loading with 10 fold copper excess [94]. The dependency of copper loading time on intracellular copper level is likely to be attributed to rapid $\left(>0.1 \mathrm{~s}^{-1}\right)$ copper binding to a second, reversible, pre-equilibrium "kinetic" site on CAO [93]. It was also directly shown that copper level does influence CAO activity [95,96]. (3) Copper assisted putrescine catabolism to GABA provides elevated intracellular GABA and enhanced GABA release. (4) GABA release through outward open GAT-3 triggers the enhancement of tonic inhibitory currents via activation of the extrasynaptic $\mathrm{GABA}_{\mathrm{a}}$ receptor subtype. (5) $\mathrm{Cu}^{2+}$ may also bind to the extracellular $\mathrm{Zn}^{2+}$ binding sites of the GAT-3 transporter, keeping GAT-3 open and therefore facilitating GABA release. (6) On the other hand, putrescine is also used to synthesize spermine which keeps gap junction channels (GJCs) open and enables intercellular trafficking of $\mathrm{Ca}^{2+}$ and other messengers. (7) Alternatively, GABA can also spread 
through the GJCs and released at distant astroglial processes through $\mathrm{P}_{2} \mathrm{X}_{7}$ purinergic receptor pores or $\mathrm{C} \times 43$ hemichannels.

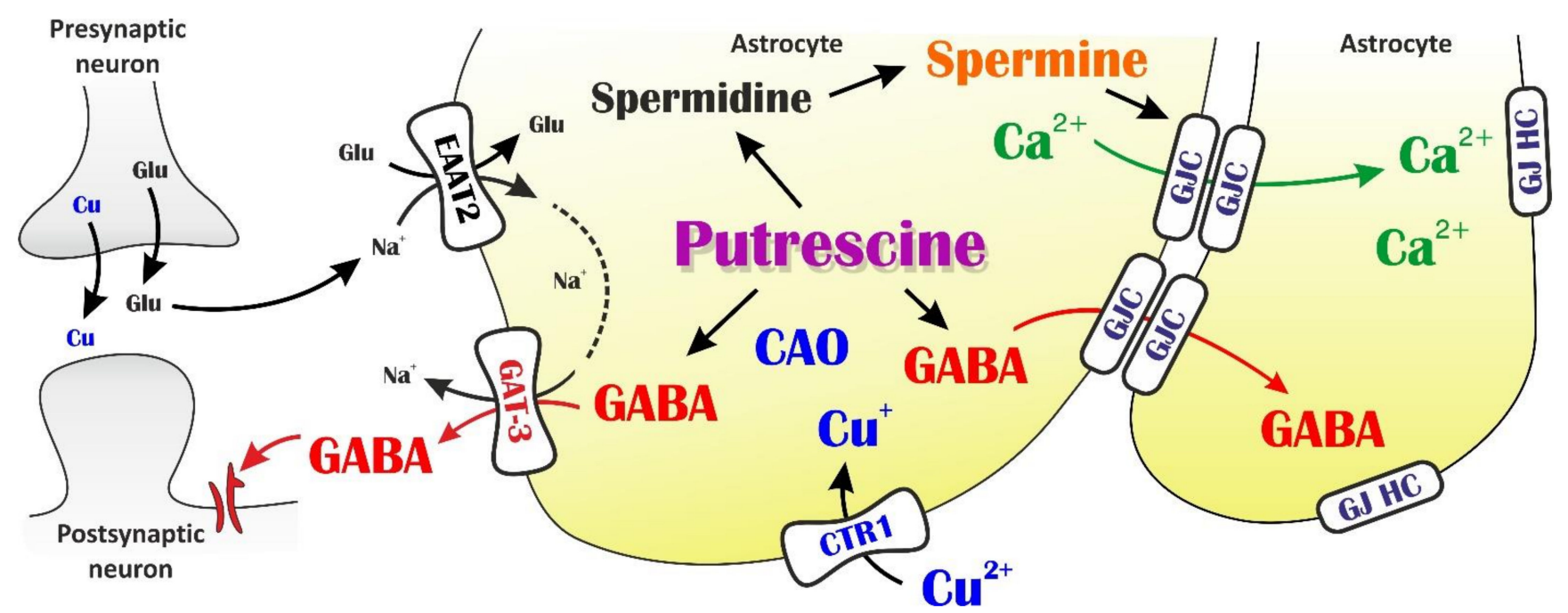

Figure 4. Schematic representation of dual role for astroglial copper-assisted polyamine metabolism in controlling neuronal excitability. Astrocytic putrescine can be catabolised to GABA and this GABA can release to the extrasynaptic space in response to Glu transporter (EAAT)-mediated $\mathrm{Na}^{+}$influx. The released GABA generate tonic current on extrasynaptic GABAa receptors. Since the putrescine-GABA conversion is catalyzed by copper containing amine oxidases (CAOs), intracellular copper level can influence the amount of GABA accumulated in astrocytes. By inhibiting or stimulating the astrocytic copper transporter CTR1, the releasable GABA pool can be controlled. On the other hand, putrescine is also metabolized to spermine which contributes to opening of gap junction channels (GJCs), through which $\mathrm{Ca}^{2+}$ and other substances can be redistributed through the astrocytic syncytium and consequently neuronal activity is spread over a large area.

Consequently, astrocytic putrescine metabolism simultaneously participates both in reduction and enhancement of neuronal activity by providing tonic GABA currents and GJC-mediated activity-spreading, respectively.

The amount of copper released into the synapse, diffused extra-synaptically and taken up by astroglial copper transporters determines the strength of redox coupling which may vary from physiological to up- or down-regulated. The high extracellular level of copper elicits low surface expression of CTR1 [44], that may be mechanistically linked to Parkinson's and Alzheimer's disease mechanisms [97,98] or schizophrenia [99]. Metabolic profiling of brains [100-102] and serum [103] of AD subjects suggests a possible role for altered spermidine metabolism correlating AD indicators. Further studies may also substantiate spermidine-associated change of putrescine and GABA that can serve as early serum biomarkers for $\mathrm{AD}$ progression in the future.

Author Contributions: Conceptualization, J.K., L.H.; methodology and formal analysis, L.H., Z.S.; investigation, Z.S.; data handling, L.H.; Z.S.; M.P.; original draft preparation, J.K.; writing and editing, J.K., L.H., Z.S.; visualization, L.H.; supervision, L.H.; project administration, L.H.; funding acquisition, L.H. All authors have read and agreed to the published version of the manuscript.

Funding: This research was partly supported by the grant OTKA K124558. László Héja is a recipient of the János Bolyai Scholarship of the Hungarian Academy of Sciences.

Institutional Review Board Statement: The study was conducted according to the guidelines of the Declaration of Helsinki, and approved by the Animal Care Committee of Research Centre for Natural Sciences and the Government Office for Pest County (Reference Nos. PEI/001/3671-4/2015 and $\mathrm{PE} / \mathrm{EA} / 3840-4 / 2016)$.

Informed Consent Statement: Not applicable. 
Data Availability Statement: The data supporting this manuscript is available upon request to the corresponding author (László Héja, heja.laszlo@ttk.hu).

Acknowledgments: The authors are grateful to Erzsébet Fekete-Kúti for technical assistance.

Conflicts of Interest: The authors declare that they have no potential conflict of interest that could be perceived as prejudicing the impartiality of the research presented herein.

\section{References}

1. Caudal, L.C.; Gobbo, D.; Scheller, A.; Kirchhoff, F. The Paradox of Astroglial $\mathrm{Ca}_{2+}$ Signals at the Interface of Excitation and Inhibition. Front. Cell. Neurosci. 2020, 14, 399. [CrossRef] [PubMed]

2. Cho, J.; Huh, Y. Astrocytic Calcium Dynamics Along the Pain Pathway. Front. Cell. Neurosci. 2020, 14, 333. [CrossRef] [PubMed]

3. De Pittà, M. Neuron-Glial Interactions. In Encyclopedia of Computational Neuroscience; Springer: New York, NY, USA, 2020; pp. $1-30$.

4. Yoon, B.-E.; Jo, S.; Woo, J.; Lee, J.-H.; Kim, T.; Kim, D.; Lee, C.J. The amount of astrocytic GABA positively correlates with the degree of tonic inhibition in hippocampal CA1 and cerebellum. Mol. Brain 2011, 4, 42. [CrossRef] [PubMed]

5. Ma, X.; Lubin, H.; Ioja, E.; Kékesi, O.; Simon, Á.; Apáti, Á.; Orbán, T.I.; Héja, L.; Kardos, J.; Markó, I.E. Straightforward and effective synthesis of $\gamma$-aminobutyric acid transporter subtype 2-selective acyl-substituted azaspiro[4.5]decanes. Bioorg. Med. Chem. Lett. 2016, 26. [CrossRef]

6. Semyanov, A.; Henneberger, C.; Agarwal, A. Making sense of astrocytic calcium signals—From acquisition to interpretation. Nat. Rev. Neurosci. 2020, 21, 551-564. [CrossRef]

7. Zhou, Y.; Shao, A.; Yao, Y.; Tu, S.; Deng, Y.; Zhang, J. Dual roles of astrocytes in plasticity and reconstruction after traumatic brain injury. Cell Commun. Signal. 2020, 18. [CrossRef]

8. Szabó, Z.; Héja, L.; Szalay, G.; Kékesi, O.; Füredi, A.; Szebényi, K.; Dobolyi, Á.; Orbán, T.I.; Kolacsek, O.; Tompa, T.; et al. Extensive astrocyte synchronization advances neuronal coupling in slow wave activity in vivo. Sci. Rep. 2017, 7, 6018. [CrossRef]

9. Felix, L.; Stephan, J.; Rose, C.R. Astrocytes of the early postnatal brain. Eur. J. Neurosci. 2020. [CrossRef]

10. Héja, L.; Simon, Á.; Szabó, Z.; Kardos, J. Feedback adaptation of synaptic excitability via Glu:Na ${ }^{+}$symport driven astrocytic GABA and Gln release. Neuropharmacology 2019, 161. [CrossRef]

11. Fiacco, T.A.; McCarthy, K.D. Multiple lines of evidence indicate that gliotransmission does not occur under physiological conditions. J. Neurosci. 2018, 38. [CrossRef]

12. Savtchouk, I.; Volterra, A. Gliotransmission: Beyond black-and-white. J. Neurosci. 2018, 38. [CrossRef]

13. Braganza, O.; Bedner, P.; Hüttmann, K.; von Staden, E.; Friedman, A.; Seifert, G.; Steinhäuser, C. Albumin is taken up by hippocampal NG2 cells and astrocytes and decreases gap junction coupling. Epilepsia 2012, 53, 1898-1906. [CrossRef]

14. Nagatomo, K.; Ueda, Y.; Doi, T.; Takaki, M.; Tsuru, N. Functional role of GABA transporters for kindling development in GLAST KO mice. Neurosci Res 2007, 57, 319-321. [CrossRef]

15. Unichenko, P.; Dvorzhak, A.; Kirischuk, S. Transporter-mediated replacement of extracellular glutamate for GABA in the developing murine neocortex. Eur. J. Neurosci. 2013, 38, 3580-3588. [CrossRef]

16. Verhoog, Q.P.; Holtman, L.; Aronica, E.; van Vliet, E.A. Astrocytes as Guardians of Neuronal Excitability: Mechanisms Underlying Epileptogenesis. Front. Neurol. 2020, 11, 591690. [CrossRef]

17. Héja, L.; Szabó, Z.; Péter, M.; Kardos, J. Spontaneous Ca2+ Fluctuations Arise in Thin Astrocytic Processes with Real 3D Geometry. Front. Cell. Neurosci. 2021, 15, 617989. [CrossRef]

18. Henneberger, C.; Papouin, T.; Oliet, S.H.R.; Rusakov, D.A. Long-term potentiation depends on release of D-serine from astrocytes. Nature 2010, 463, 232-236. [CrossRef]

19. Henneberger, C.; Bard, L.; Panatier, A.; Reynolds, J.P.; Kopach, O.; Medvedev, N.I.; Minge, D.; Herde, M.K.; Anders, S.; Kraev, I.; et al. LTP Induction Boosts Glutamate Spillover by Driving Withdrawal of Perisynaptic Astroglia. Neuron 2020, 108, 919-936.e11. [CrossRef]

20. Inyushin, M.; Kucheryavykh, L.Y.; Kucheryavykh, Y.V.; Nichols, C.G.; Buono, R.J.; Ferraro, T.N.; Skatchkov, S.N.; Eaton, M.J. Potassium channel activity and glutamate uptake are impaired in astrocytes of seizure-susceptible DBA/2 mice. Epilepsia 2010, 51. [CrossRef]

21. Lee, S.; Yoon, B.-E.; Berglund, K.; Oh, S.-J.; Park, H.; Shin, H.-S.; Augustine, G.J.; Lee, C.J. Channel-mediated tonic GABA release from glia. Science 2010, 330, 790-796. [CrossRef]

22. Matsui, K.; Jahr, C.E.; Rubio, M.E. High-concentration rapid transients of glutamate mediate neural-glial communication via ectopic release. J. Neurosci. 2005, 25, 7538-7547. [CrossRef]

23. Pál, I.; Kardos, J.; Dobolyi, Á.; Héja, L. Appearance of fast astrocytic component in voltage-sensitive dye imaging of neural activity. Mol. Brain 2015, 8. [CrossRef]

24. Mederos, S.; Sánchez-Puelles, C.; Esparza, J.; Valero, M.; Ponomarenko, A.; Perea, G. GABAergic signaling to astrocytes in the prefrontal cortex sustains goal-directed behaviors. Nat. Neurosci. 2021, 24. [CrossRef]

25. Héja, L.; Barabás, P.; Nyitrai, G.; Kékesi, K.A.K.A.; Lasztóczi, B.; Toke, O.; Tárkányi, G.; Madsen, K.; Schousboe, A.; Dobolyi, A.; et al. Glutamate uptake triggers transporter-mediated GABA release from astrocytes. PLoS ONE 2009, 4, e7153. [CrossRef] 
26. Héja, L.; Nyitrai, G.; Kékesi, O.; Dobolyi, A.; Szabó, P.; Fiáth, R.; Ulbert, I.; Pál-Szenthe, B.; Palkovits, M.; Kardos, J. Astrocytes convert network excitation to tonic inhibition of neurons. BMC Biol. 2012, 10, 26. [CrossRef]

27. Yoon, B.-E.; Woo, J.; Chun, Y.-E.; Chun, H.; Jo, S.; Bae, J.Y.; An, H.; Min, J.O.; Oh, S.-J.; Han, K.-S.; et al. Glial GABA, synthesized by monoamine oxidase B, mediates tonic inhibition. J. Physiol. 2014, 592, 4951-4968. [CrossRef]

28. Jo, S.; Yarishkin, O.; Hwang, Y.J.; Chun, Y.E.; Park, M.; Woo, D.H.; Bae, J.Y.; Kim, T.; Lee, J.; Chun, H.; et al. GABA from reactive astrocytes impairs memory in mouse models of Alzheimer's disease. Nat. Med. 2014, 20, 886-896. [CrossRef]

29. Ormel, L.; Lauritzen, K.H.; Schreiber, R.; Kunzelmann, K.; Gundersen, V. GABA, but Not Bestrophin-1, Is Localized in Astroglial Processes in the Mouse Hippocampus and the Cerebellum. Front. Mol. Neurosci. 2020, 13. [CrossRef]

30. Skatchkov, S.N.; Bukauskas, F.F.; Benedikt, J.; Inyushin, M.; Kucheryavykh, Y.V. Intracellular spermine prevents acid-induced uncoupling of Cx43 gap junction channels. Neuroreport 2015, 26. [CrossRef]

31. Kucheryavykh, L.Y.; Benedikt, J.; Cubano, L.A.; Skatchkov, S.N.; Bukauskas, F.F.; Kucheryavykh, Y.V. Polyamines preserve connexin 43-mediated gap junctional communication during intracellular hypercalcemia and acidosis. Neuroreport $2017,28$. [CrossRef]

32. Kim, J.I.; Ganesan, S.; Luo, S.X.; Wu, Y.W.; Park, E.; Huang, E.J.; Chen, L.; Ding, J.B. Aldehyde dehydrogenase 1a1 mediates a GABA synthesis pathway in midbrain dopaminergic neurons. Science 2015, 350. [CrossRef] [PubMed]

33. Laschet, J.; Grisar, T.; Bureau, M.; Guillaume, D. Characteristics of putrescine uptake and subsequent GABA formation in primary cultured astrocytes from normal C57BL/6J and epileptic DBA/2J mouse brain cortices. Neuroscience 1992, 48, 151-157. [CrossRef]

34. Laube, G.; Veh, R.W. Astrocytes, not neurons, show most prominent staining for spermidine/spermine-like immunoreactivity in adult rat brain. Glia 1997, 19. [CrossRef]

35. Kremzner, L.T.; Hiller, J.M.; Simon, E.J. Metabolism of Polyamines in Mouse Neuroblastoma Cells in Culture: Formation of Gaba and Putreanine. J. Neurochem. 1975, 25. [CrossRef] [PubMed]

36. Seiler, N.; Al-Therib, M.J.; Kataoka, K. Formation of Gaba from Putrescine in the Brain of Fish (Salmo irideus gibb.). J. Neurochem. 1973, 20. [CrossRef]

37. Seiler, N. On the role of GABA in vertebrate polyamine metabolism. Physiol. Chem. Phys. 1980, 12, 411-429. [PubMed]

38. Seiler, N. Polyamine Metabolism. Digestion 1990, 46, 319-330. [CrossRef]

39. Lopes de Carvalho, L.; Bligt-Lindén, E.; Ramaiah, A.; Johnson, M.S.; Salminen, T.A. Evolution and functional classification of mammalian copper amine oxidases. Mol. Phylogenet. Evol. 2019, 139. [CrossRef]

40. Chang, C.J. Searching for harmony in transition-metal signaling. Nat. Chem. Biol. 2015, 11, 744-747. [CrossRef]

41. Kardos, J.; Héja, L.; Simon, Á.; Jablonkai, I.; Kovács, R.; Jemnitz, K. Copper signalling: Causes and consequences. Cell Commun. Signal. 2018, 16. [CrossRef]

42. Kardos, J.; Kovács, I.; Hajós, F.; Kálmán, M.; Simonyi, M. Nerve endings from rat brain tissue release copper upon depolarization. A possible role in regulating neuronal excitability. Neurosci. Lett. 1989, 103. [CrossRef]

43. Boyd, S.D.; Ullrich, M.S.; Skopp, A.; Winkler, D.D. Copper sources for sod1 activation. Antioxidants 2020, 9. [CrossRef]

44. Liang, Z.D.; Long, Y.; Chen, H.H.W.; Savaraj, N.; Kuo, M.T. Regulation of the high-affinity copper transporter (hCtr1) expression by cisplatin and heavy metals. J. Biol. Inorg. Chem. 2014, 19. [CrossRef]

45. Lee, J.; Peña, M.M.O.; Nose, Y.; Thiele, D.J. Biochemical characterization of the human copper transporter Ctr1. J. Biol. Chem. 2002, 277. [CrossRef]

46. Wolff, N.A.; Garrick, M.D.; Zhao, L.; Garrick, L.M.; Ghio, A.J.; Thévenod, F. A role for divalent metal transporter (DMT1) in mitochondrial uptake of iron and manganese. Sci. Rep. 2018, 8. [CrossRef]

47. Kern, A.D.; Oliveira, M.A.; Coffino, P.; Hackert, M.L. Structure of mammalian ornithine decarboxylase at $1.6 \AA$ resolution: Stereochemical implications of PLP-dependent amino acid decarboxylases. Structure 1999, 7. [CrossRef]

48. Lenis, Y.Y.; Elmetwally, M.A.; Maldonado-Estrada, J.G.; Bazer, F.W. Physiological importance of polyamines. Zygote 2017, 25. [CrossRef]

49. Bae, D.H.; Lane, D.J.R.; Jansson, P.J.; Richardson, D.R. The old and new biochemistry of polyamines. Biochim. Biophys. Acta Gen. Subj. 2018, 1862, 2053-2068. [CrossRef]

50. Baroli, G.; Sanchez, J.R.; Agostinelli, E.; Mariottini, P.; Cervelli, M. Polyamines: The possible missing link between mental disorders and epilepsy (Review). Int. J. Mol. Med. 2020, 45, 3-9. [CrossRef]

51. Van Veen, S.; Martin, S.; Van den Haute, C.; Benoy, V.; Lyons, J.; Vanhoutte, R.; Kahler, J.P.; Decuypere, J.P.; Gelders, G.; Lambie, E.; et al. ATP13A2 deficiency disrupts lysosomal polyamine export. Nature 2020, 578. [CrossRef]

52. Vrijsen, S.; Besora-Casals, L.; Van Veen, S.; Zielich, J.; Van Den Haute, C.; Hamouda, N.N.; Fischer, C.; Ghesquière, B.; Tournev, I.; Agostinis, P.; et al. ATP13A2-mediated endo-lysosomal polyamine export counters mitochondrial oxidative stress. Proc. Natl. Acad. Sci. USA 2020, 117. [CrossRef]

53. Lane, D.J.R.; Bae, D.H.; Siafakas, A.R.; Suryo Rahmanto, Y.; Al-Akra, L.; Jansson, P.J.; Casero, R.A.; Richardson, D.R. Coupling of the polyamine and iron metabolism pathways in the regulation of proliferation: Mechanistic links to alterations in key polyamine biosynthetic and catabolic enzymes. Biochim. Biophys. Acta Mol. Basis Dis. 2018, 1864. [CrossRef]

54. Skatchkov, S.N.; Antonov, S.M.; Eaton, M.J. Glia and glial polyamines. Role in brain function in health and disease. Biochem. Suppl. Ser. A Membr. Cell Biol. 2016, 10, 73-98. [CrossRef]

55. Skatchkov, S.N.; Woodbury-Fariña, M.A.; Eaton, M. The role of glia in stress: Polyamines and brain disorders. Psychiatr. Clin. North Am. 2014, 37. 
56. Handa, A.K.; Fatima, T.; Mattoo, A.K. Polyamines: Bio-Molecules with Diverse Functions in Plant and Human Health and Disease. Front. Chem. 2018, 6. [CrossRef]

57. Jain, V.; Raina, S.; Gheware, A.P.; Singh, R.; Rehman, R.; Negi, V.; Murray Stewart, T.; Mabalirajan, U.; Mishra, A.K.; Casero, R.A.; et al. Reduction in polyamine catabolism leads to spermine-mediated airway epithelial injury and induces asthma features. Allergy Eur. J. Allergy Clin. Immunol. 2018, 73. [CrossRef]

58. Kahana, C. The antizyme family for regulating polyamines. J. Biol. Chem. 2018, 293, 18730-18735. [CrossRef]

59. Mahajan, U.V.; Varma, V.R.; Griswold, M.E.; Blackshear, C.T.; An, Y.; Oommen, A.M.; Varma, S.; Troncoso, J.C.; Pletnikova, O.; O'Brien, R.; et al. Dysregulation of multiple metabolic networks related to brain transmethylation and polyamine pathways in Alzheimer disease: A targeted metabolomic and transcriptomic study. PLoS Med. 2020, 17. [CrossRef]

60. Makletsova, M.G.; Syatkin, S.P.; Poleshchuk, V.V.; Urazgildeeva, G.R.; Chigaleychik, L.A.; Sungrapova, C.Y.; Illarioshkin, S.N Polyamines in Parkinson's Disease: Their Role in Oxidative Stress Induction and Protein Aggregation. J. Neurol. Res. 2019, 9. [CrossRef]

61. Miller-Fleming, L.; Olin-Sandoval, V.; Campbell, K.; Ralser, M. Remaining Mysteries of Molecular Biology: The Role of Polyamines in the Cell. J. Mol. Biol. 2015, 427, 3389-3406. [CrossRef]

62. Pegg, A.E. Functions of polyamines in mammals. J. Biol. Chem. 2016, 291, 14904-14912. [CrossRef] [PubMed]

63. Sánchez-Jiménez, F.; Medina, M.Á.; Villalobos-Rueda, L.; Urdiales, J.L. Polyamines in mammalian pathophysiology. Cell. Mol. Life Sci. 2019, 76, 3987-4008. [CrossRef] [PubMed]

64. Beckonert, N.M.; Opitz, T.; Pitsch, X.; da Silva, P.S.; Beck, H. Polyamine modulation of anticonvulsant drug response: A potential mechanism contributing to pharmacoresistance in chronic epilepsy. J. Neurosci. 2018, 38. [CrossRef] [PubMed]

65. Derera, I.D.; Dulla, C.G. THAR SHE BLOWS! The Search for the Great Spermine Whale of Carbamazepine Resistance. Epilepsy Curr. 2019, 19, 59-61. [CrossRef]

66. Kapfhamer, D.; McKenna, J.; Yoon, C.J.; Murray-Stewart, T.; Casero, R.A.; Gambello, M.J. Ornithine decarboxylase, the ratelimiting enzyme of polyamine synthesis, modifies brain pathology in a mouse model of tuberous sclerosis complex. Hum. Mol. Genet. 2020, 29. [CrossRef]

67. Fredriksson, R.; Sreedharan, S.; Nordenankar, K.; Alsiö, J.; Lindberg, F.A.; Hutchinson, A.; Eriksson, A.; Roshanbin, S.; Ciuculete, D.M.; Klockars, A.; et al. The polyamine transporter Slc18b1(VPAT) is important for both short and long time memory and for regulation of polyamine content in the brain. PLoS Genet. 2019, 15. [CrossRef]

68. Guerra, G.P.; Rubin, M.A.; Mello, C.F. Modulation of learning and memory by natural polyamines. Pharmacol. Res. 2016, 112, 99-118. [CrossRef]

69. Anderson, J.G.; Fordahl, S.C.; Cooney, P.T.; Weaver, T.L.; Colyer, C.L.; Erikson, K.M. Manganese exposure alters extracellular GABA, GABA receptor and transporter protein and mRNA levels in the developing rat brain. Neurotoxicology 2008, 29. [CrossRef]

70. Kardos, J.; Héja, L.; Jemnitz, K.; Kovács, R.; Palkovits, M. The nature of early astroglial protection-Fast activation and signaling. Prog. Neurobiol. 2017, 153. [CrossRef]

71. Assaf, S.Y.; Chung, S.H. Release of endogenous Zn2+ from brain tissue during activity. Nature 1984, 308. [CrossRef]

72. Krzywoszyńska, K.; Witkowska, D.; Swiatek-kozlowska, J.; Szebesczyk, A.; Kozłowski, H. General aspects of metal ions as signaling agents in health and disease. Biomolecules 2020, 10, 1417. [CrossRef]

73. Frederickson, C.J.; Bush, A.I. Synaptically released zinc: Physiological functions and pathological effects. BioMetals 2001, 14, 353-366. [CrossRef]

74. Cohen-Kfir, E.; Lee, W.; Eskandari, S.; Nelson, N. Zinc inhibition of $\gamma$-aminobutyric acid transporter 4 (GAT4) a link between excitatory and inhibitory neurotransmission. Proc. Natl. Acad. Sci. USA 2005, 102, 6154-6159. [CrossRef]

75. Kardos, J.; Pallo, A.; Bencsura, A.; Simon, A. Assessing Structure, Function and Druggability of Major Inhibitory Neurotransmitter -Aminobutyrate Symporter Subtypes. Curr. Med. Chem. 2010, 17, 2203-2213. [CrossRef]

76. Palló, A.; Simon, A.; Bencsura, A.; Héja, L.; Kardos, J. Substrate-Na+ complex formation: Coupling mechanism for gammaaminobutyrate symporters. Biochem. Biophys. Res. Commun. 2009, 385, 210-214. [CrossRef]

77. Weber, D.S.; Warren, J.J. The interaction between methionine and two aromatic amino acids is an abundant and multifunctional motif in proteins. Arch. Biochem. Biophys. 2019, 672. [CrossRef]

78. Yeung, P.S.W.; Ing, C.E.; Yamashita, M.; Pomès, R.; Prakriya, M. A sulfur-aromatic gate latch is essential for opening of the orai1 channel pore. Elife 2020, 9. [CrossRef]

79. Fordahl, S.C.; Anderson, J.G.; Cooney, P.T.; Weaver, T.L.; Colyer, C.L.; Erikson, K.M. Manganese exposure inhibits the clearance of extracellular GABA and influences taurine homeostasis in the striatum of developing rats. Neurotoxicology 2010, 31. [CrossRef]

80. Carrillo, E.; Bhatia, N.K.; Akimzhanov, A.M.; Jayaraman, V. Activity dependent inhibition of AMPA receptors by Zn2+. J. Neurosci. 2020, 40. [CrossRef]

81. Fisher, J.L.; Macdonald, R.L. The role of an $\alpha$ subtype M2-M3 his in regulating inhibition of GABA(A) receptor current by zinc and other divalent cations. J. Neurosci. 1998, 18, 2944-2953. [CrossRef]

82. Granzotto, A.; Canzoniero, L.M.T.; Sensi, S.L. A Neurotoxic Ménage-à-trois: Glutamate, Calcium, and Zinc in the Excitotoxic Cascade. Front. Mol. Neurosci. 2020, 13, 225. [CrossRef]

83. Hosie, A.M.; Dunne, E.L.; Harvey, R.J.; Smart, T.G. Zinc-mediated inhibition of GABAA receptors: Discrete binding sites underlie subtype specificity. Nat. Neurosci. 2003, 6, 362-369. [CrossRef]

84. Krall, R.F.; Tzounopoulos, T.; Aizenman, E. The Function and Regulation of Zinc in the Brain. Neuroscience 2021. [CrossRef] 
85. Kardos, J. The GABAA receptor channel mediated chloride ion translocation through the plasma membrane: New insights from 36Cl- ion flux measurements. Synapse 1993, 13, 74-93. [CrossRef]

86. Paoletti, P.; Vergnano, A.M.; Barbour, B.; Casado, M. Zinc at glutamatergic synapses. Neuroscience 2009, 158, 126-136. [CrossRef]

87. Wu, Q.; Wada, M.; Shimada, A.; Yamamoto, A.; Fujita, T. Functional characterization of Zn2+-sensitive GABA transporter expressed in primary cultures of astrocytes from rat cerebral cortex. Brain Res. 2006, 1075. [CrossRef]

88. Fernandes, J.; Chandler, J.D.; Liu, K.H.; Uppal, K.; Go, Y.M.; Jones, D.P. Putrescine as indicator of manganese neurotoxicity: Dose-response study in human SH-SY5Y cells. Food Chem. Toxicol. 2018, 116. [CrossRef] [PubMed]

89. Browne, L.E.; Compan, V.; Bragg, L.; North, R.A. P2X7 receptor channels allow direct permeation of nanometer-sized dyes. J. Neurosci. 2013, 33. [CrossRef] [PubMed]

90. Ye, Z.C.; Wyeth, M.S.; Baltan-Tekkok, S.; Ransom, B.R. Functional hemichannels in astrocytes: A novel mechanism of glutamate release. J. Neurosci. 2003, 23. [CrossRef]

91. Stuerenburg, H.J. CSF copper concentrations, blood-brain barrier function, and coeruloplasmin synthesis during the treatment of Wilson's disease. J. Neural Transm. 2000, 107. [CrossRef] [PubMed]

92. Maureira, C.; Letelier, J.C.; Alvarez, O.; Delgado, R.; Vergara, C. Copper enhances cellular and network excitabilities, and improves temporal processing in the rat hippocampus. Eur. J. Neurosci. 2015, 42. [CrossRef] [PubMed]

93. Adelson, C.N.; Johnston, E.M.; Hilmer, K.M.; Watts, H.; Dey, S.G.; Brown, D.E.; Broderick, J.B.; Shepard, E.M.; Dooley, D.M.; Solomon, E.I. Characterization of the Preprocessed Copper Site Equilibrium in Amine Oxidase and Assignment of the Reactive Copper Site in Topaquinone Biogenesis. J. Am. Chem. Soc. 2019, 141. [CrossRef]

94. Ruggiero, C.E.; Dooley, D.M. Stoichiometry of the topa quinone biogenesis reaction in copper amine oxidases. Biochemistry 1999, 38. [CrossRef]

95. Kehoe, C.A.; Faughnan, M.S.; Gilmore, W.S.; Coulter, J.S.; Howard, A.N.; Strain, J.J. Plasma diamine oxidase activity is greater in copper-adequate than copper-marginal or copper-deficient rats. J. Nutr. 2000, 130. [CrossRef]

96. Disilvestro, R.A.; Jones, A.A.; Smith, D.; Wildman, R. Plasma diamine oxidase activities in renal dialysis patients, a human with spontaneous copper deficiency and marginally copper deficient rats. Clin. Biochem. 1997, 30. [CrossRef]

97. Gou, D.H.; Huang, T.T.; Li, W.; Gao, X.D.; Haikal, C.; Wang, X.H.; Song, D.Y.; Liang, X.; Zhu, L.; Tang, Y.; et al. Inhibition of copper transporter 1 prevents $\alpha$-synuclein pathology and alleviates nigrostriatal degeneration in AAV-based mouse model of Parkinson's disease. Redox Biol. 2021, 38. [CrossRef]

98. Wang, L.; Yin, Y.L.; Liu, X.Z.; Shen, P.; Zheng, Y.G.; Lan, X.R.; Lu, C.B.; Wang, J.Z. Current understanding of metal ions in the pathogenesis of Alzheimer's disease. Transl. Neurodegener. 2020, 9. [CrossRef]

99. Schoonover, K.E.; Farmer, C.B.; Morgan, C.J.; Sinha, V.; Odom, L.; Roberts, R.C. Abnormalities in the copper transporter CTR1 in postmortem hippocampus in schizophrenia: A subregion and laminar analysis. Schizophr. Res. 2021, 228. [CrossRef]

100. Inoue, K.; Tsutsui, H.; Akatsu, H.; Hashizume, Y.; Matsukawa, N.; Yamamoto, T.; Toyo'Oka, T. Metabolic profiling of Alzheimer's disease brains. Sci. Rep. 2013, 3. [CrossRef]

101. Morrison, L.D.; Cao, X.C.; Kish, S.J. Ornithine decarboxylase in human brain: Influence of aging, regional distribution, and Alzheimer's disease. J. Neurochem. 1998, 71. [CrossRef] [PubMed]

102. Morrison, L.D.; Bergeron, C.; Kish, S.J. Brain S-adenosylmethionine decarboxylase activity is increased in Alzheimer's disease. Neurosci. Lett. 1993, 154, 141-144. [CrossRef]

103. González-Domínguez, R.; García, A.; García-Barrera, T.; Barbas, C.; Gómez-Ariza, J.L. Metabolomic profiling of serum in the progression of Alzheimer's disease by capillary electrophoresis-mass spectrometry. Electrophoresis 2014, 35. [CrossRef] [PubMed] 